\title{
Progress and future directions for atomic layer deposition and ALD-based chemistry
}

\section{9}

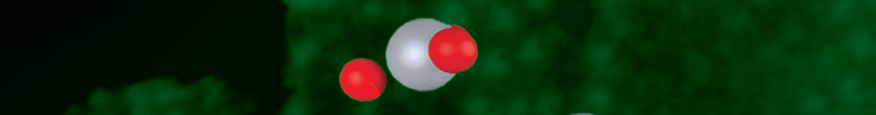

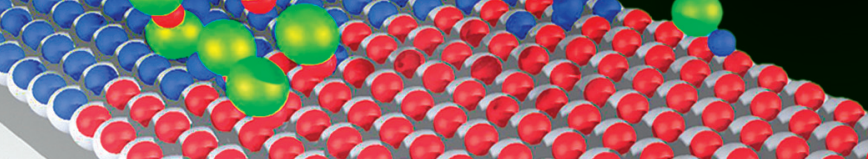

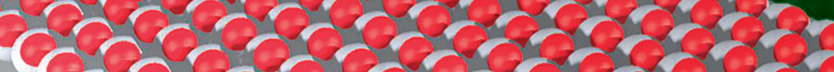

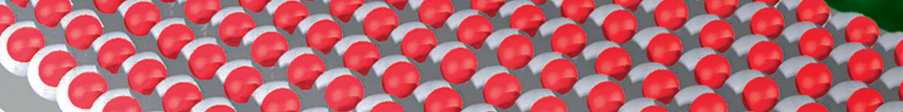

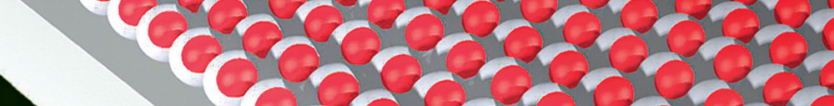
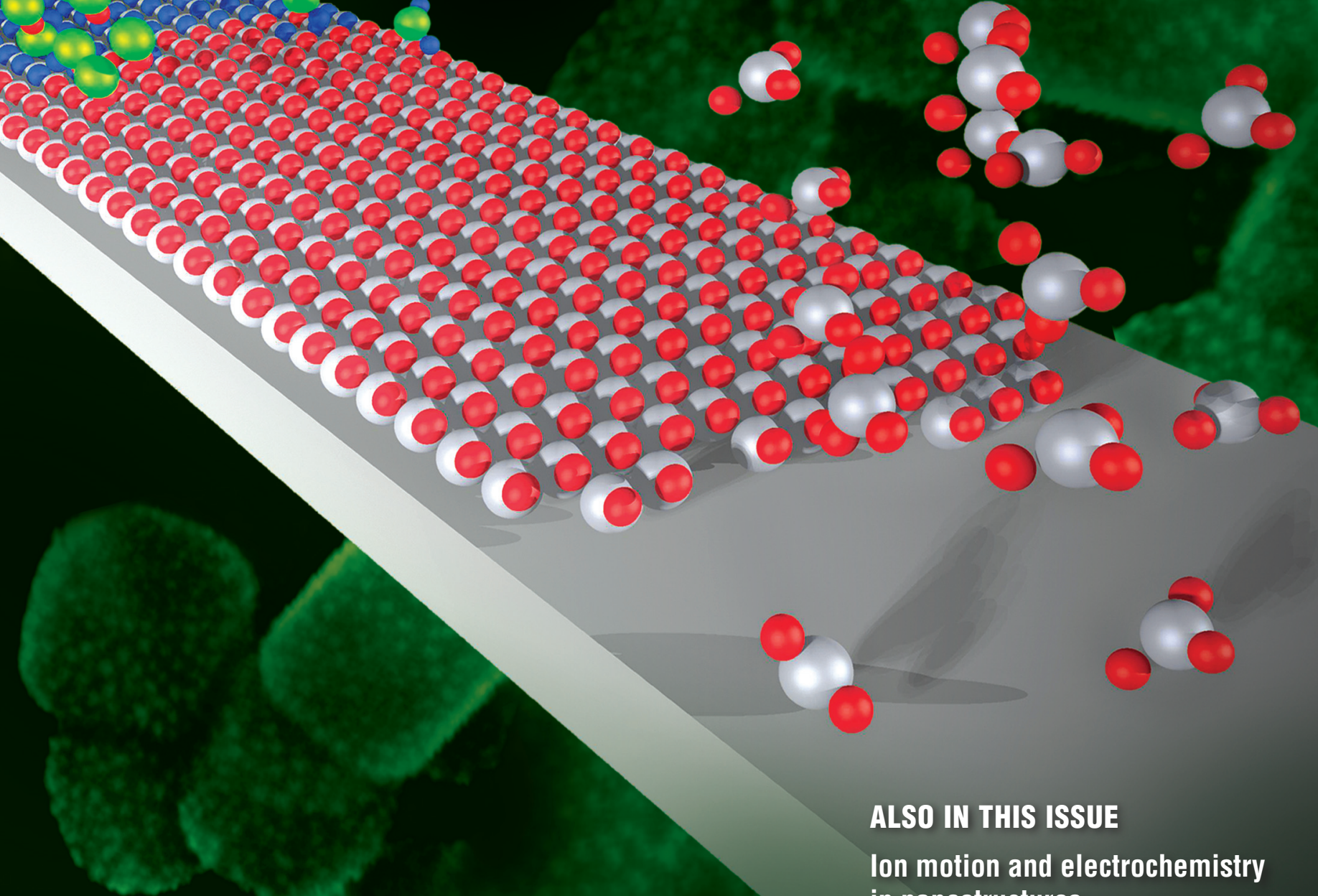

ALSO IN THIS ISSUE

Ion motion and electrochemistry in nanostructures 


\section{PARTICLE ACCELERATOR SYSTEMS}

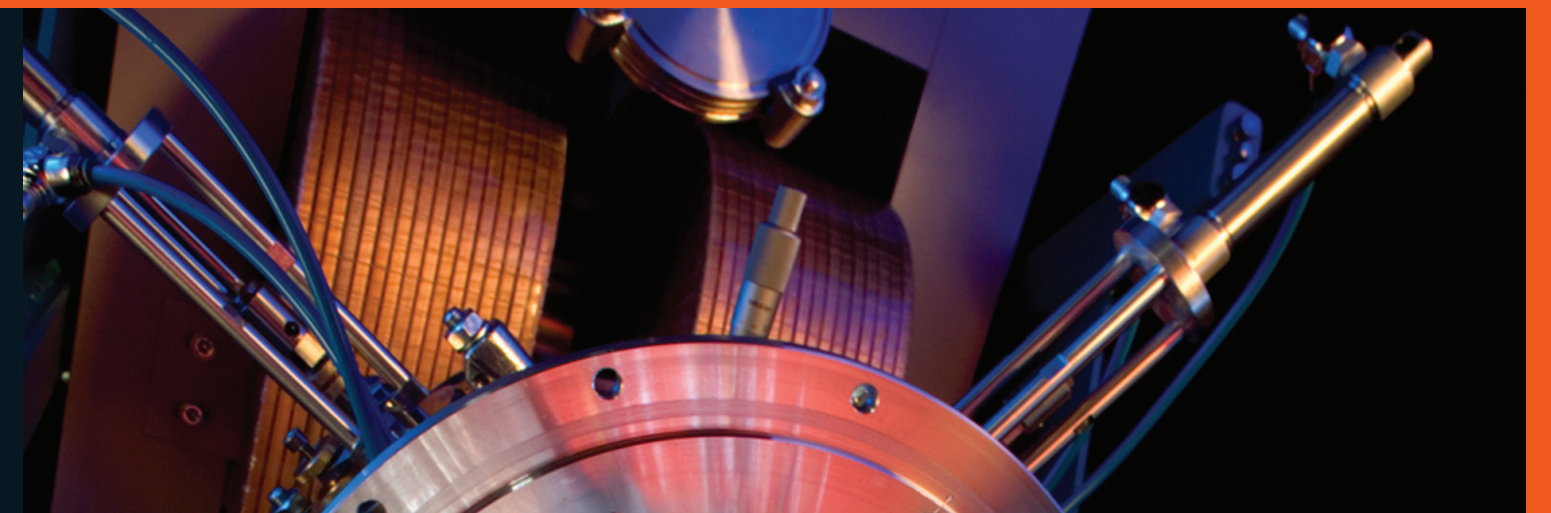

口 Ion Accelerator Systems

- Ion Implanters

- Systems for lon Beam Analysis

- Accelerator Mass Spectrometers

- Systems for $\boldsymbol{\mu}$-beam Applications

- Neutron Generator Systems

Electron Accelerator Systems

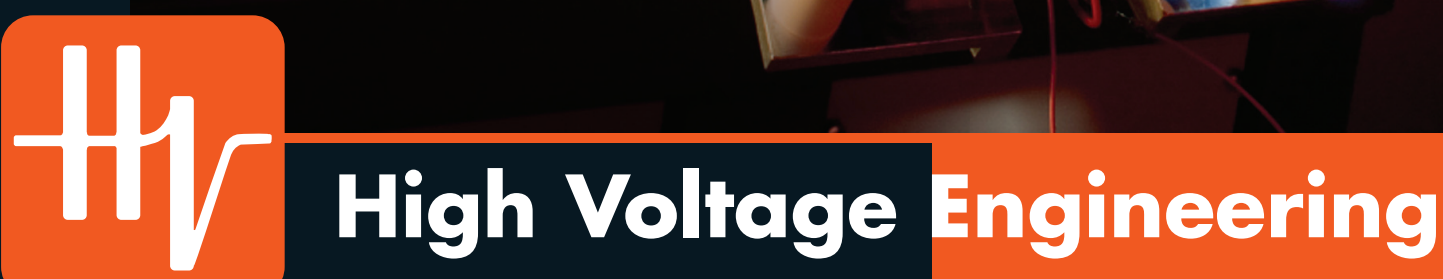

High Voltage Engineering Europa B.V.

P.O. Box 99, 3800 AB Amersfoort, The Netherlands Tel: $31334619741 \cdot$ info@highvolteng.com 


\section{The first truly global foundry}

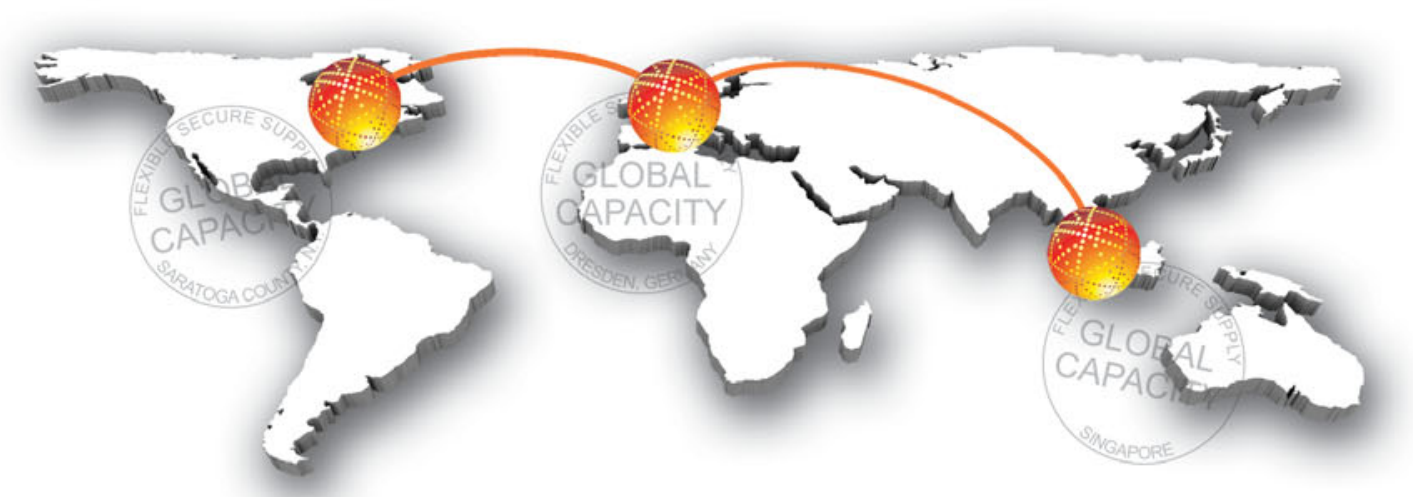

In January 2010, the semiconductor foundry landscape changed forever with the launch of the new GLOBALFOUNDRIES. This new entrant to the market combined the leading-edge integrated device manufacturing heritage of Advanced Micro Devices (AMD) with the pure-play semiconductor foundry heritage of Chartered Semiconductor to create a company with an impressive capacity and technology footprint and a world-class customer base.

Headquartered in Silicon Valley, our leading edge technology company has well over 10,000 employees with an extensive $200 \mathrm{~mm}$ and $300 \mathrm{~mm}$ silicon wafer manufacturing campus in Singapore. This is complemented by a leading-edge $300 \mathrm{~mm}$ manufacturing campus in Dresden, Germany and a third campus under construction in Saratoga County, New York, that once complete should be the most advanced in the world. These global operations provide a unique opportunity for us to attract and leverage the best engineering and technical talent from around the world to support long-term growth and expansion opportunities. 


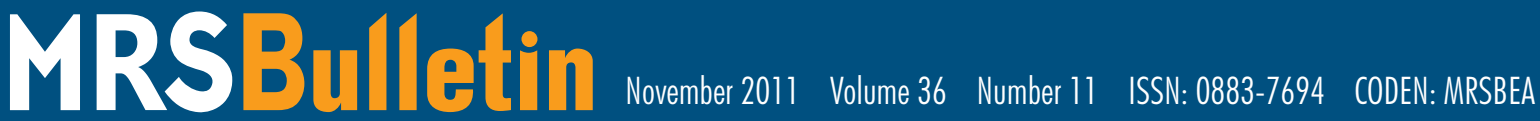
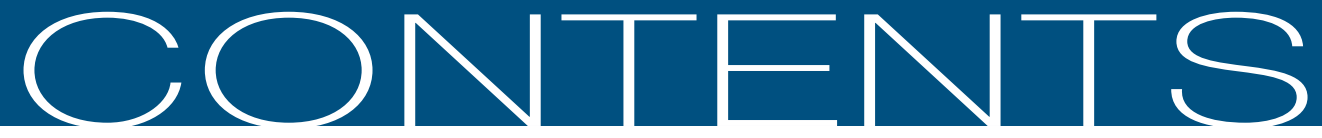

\section{PROGRESS AND FUTURE DIRECTIONS FOR ATOMIC LAYER DEPOSITION AND ALD-BASED CHEMISTRY}

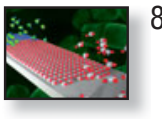

865 Progress and future directions for atomic layer deposition and ALD-based chemistry Gregory N. Parsons, Steven M. George, and Mato Knez, Guest Editors

873 Meet Our Authors

877 Novel materials by atomic layer deposition and molecular layer deposition Markku Leskelä, Mikko Ritala, and Ola Nilsen

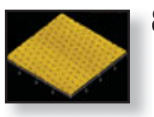

887 Surface modification and fabrication of 3D nanostructures by atomic layer deposition Changdeuck Bae, Hyunjung Shin, and Kornelius Nielsch

899 ALD for clean energy conversion, utilization, and storage

Jeffrey W. Elam, Neil P. Dasgupta, and Fritz B. Prinz

907 Advanced process technologies:

Plasma, direct-write, atmospheric pressure, and roll-to-roll ALD

W.M.M. (Erwin) Kessels and Matti Putkonen

\section{TECHNICAL FEATURE}

914 Ion motion and electrochemistry

in nanostructures

Douglas Natelson and Massimiliano Di Ventra

\section{DEPARTMENTS}

\section{OPINION}

831 Letter from the President Creating the future of MRS meetings Jim De Yoreo and Duane Dimos

833 Letters to the Editor

\section{- NEWS \& ANALYSIS}

\section{Research/Researchers}

- Novel method developed to grow graphene on low reactivity metals Steven Trohalaki

- Electronic bucket brigade could boost solar-cell voltages

- Quantum dot funnels increase solar-cell fill factor Benjamin Scheiner

- Thin-film heterostructures of $\mathrm{Fe}$ - and $\mathrm{Co}-\mathrm{BaTiO}_{3}$ exhibit interface multiferroicity at room temperature Steven Spurgeon

- Directional molecular motor rotation electrically driven

Tobias Lockwood

- Materials Researcher Dan Shechtman receives Nobel Prize for discovery of quasicrystals

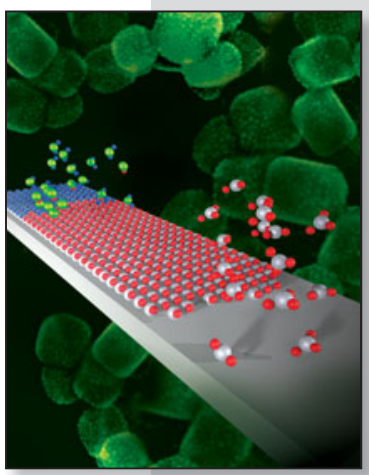

ON THE COVER

Progress and future directions for atomic layer deposition and ALDbased chemistry. This issue of MRS Bulletin details current progress in atomic layer deposition, including the extension of ALD to new regions of the periodic table, and molecular layer deposition and vapor infiltration for synthesis of organicbased thin films. The cover image shows a diagram of an ALD reaction scheme-a snapshot of the reactants and products as they would be flowing from left to right. This is a general, stylized ALD reaction scheme to visualize surface ligand exchange. The background is a scanning electron microscopy image of $2 \mathrm{~nm}$ ALD-deposited Pt nanoparticles uniformly dispersed on strontium titanate nanocubes. See the technical theme that begins on page 865 . 
853 Technology Advances

- GaN changes the game in power conversion

- Seeing more clearly at the nanoscale

860 Science Policy

- Singapore-MIT research center serves as model for innovative collaboration

Kendra Redmond

- USA, Europe collaborate on smart grid standards

\section{SOCIETY NEWS}

- Eric J. Amis to give MRS plenary address

- Zhong Lin Wang named 2011 MRS Medalist for oxide nanotechnology

- Mark E. Davis to give Kavli lecture on fighting cancer with nanoparticles

- MRS reports election results for 2012

- MRS collaborates with E-MRS on energy symposia within the $2011 \mathrm{E}-\mathrm{MRS}$ Spring Meeting/ IUMRS-ICAM Meeting

- NT11 and Satellite workshop held on metrology standardization for CNTs M.S. Dresselhaus

- Nominations requested for $€ U-40$ Materials Prize

- 2nd European Energy Conference to be held in April 2012

\section{CAREER CENTRAL}

\section{FEATURES}

\section{Beyond the Lab}

Janglin Chen's return to Taiwan brings

display vision to fruition

Prachi Patel

\section{Posterminaries}

Seeing decade by decade

Steve Moss

\section{ADVERTISERS IN THIS ISSUE}

Page No.

AccTec BV

.920

Air Liquide mon

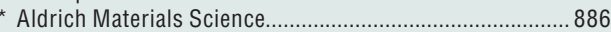

American Elements................................... Outside back cover

* American Physical Society (APS) ………....................... 847

* Asylum Research.................................................................... 840

Boston University ............................................................ 839

* Brooks Automation, Inc ....................................... 856

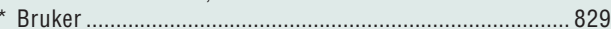

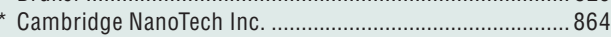

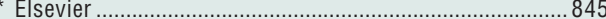

* FEl Company ……………………………………… 852, 872

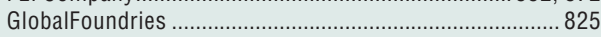

* Goodfellow Corporation _ 842

High Voltage Engineering ............................... Inside front cover

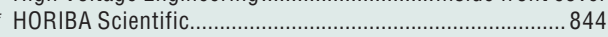

IMI-SEE International Materials Institute

for Solar Energy and Environment ................................. 843

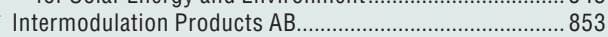

* Janis Research Company, LLC.......................................... 871

* JEOL USA, Inc. 834

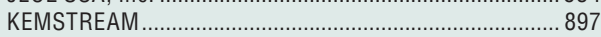

* Kurt J. Lesker Company ........................................ 830, 875

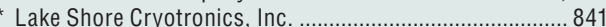

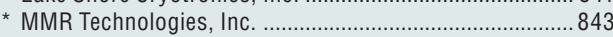

* National Electrostatics Corp............................................ 835

Picosun USA, LLC 8376

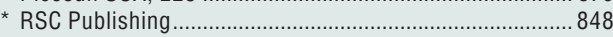

SMART Scholarship ........................................................... 851

* Solartron Analytical (AMETEK) .................... Inside back cover

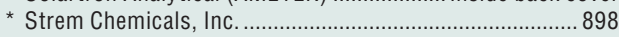

* Thermo Fisher Scientific, Inc................................................. 836

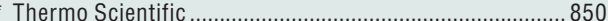

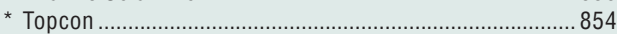

* ULVAC Technologies, Inc. .................................................... 913

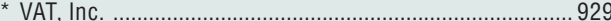

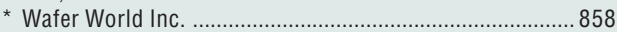

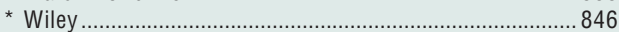

* J.A. Woollam Company, Inc................................................ 838

*Please visit us at the Exhibit, November 29-December 1, during the 2011 MRS Fall Meeting in Boston.

\section{www.mrs.org/bulletin}

MRS members-access MRS Bulletin online

www.materialsforenergy.org

Join the conversation in the Materials for Energy blog

www.mrs.org/mymrs

MRS Publications Alert-

receive advance Table of Contents by email

http://journals.cambridge.org/

mrsbulletin-rss

Subscribe TODAY to the MRS Bulletin RSS Feed 


\section{About the Materials Research Society}

The Materials Research Society (MRS), a not-for-profit scientific association founded in 1973, promotes interdisciplinary goal-oriented basic research on materials of technological importance. Membership in the Society includes almost 16,000 scientists, engineers, and research managers from industrial, government, and university research laboratories in the United States and close to 70 countries.

The Society's interdisciplinary approach differs from that of single-discipline professional societies because it promotes information exchange across the many technical fields touching materials development. MRS sponsors two major international annual meetings encompassing approximately 70 topical symposia, and also sponsors numerous single-topic scientific meetings. The Society recognizes professional and technical excellence and fosters technical interaction in local geographic regions through Sections and University Chapters.

MRS participates in the international arena of materials research through the International Union of Materials Research Societies (IUMRS). MRS is a member of ASTRA and is an affiliate of the American Institute of Physics.

MRS publishes symposium proceedings, MRS Bulletin, Journal of Materials Research, and other publications related to current research activities.

\section{MRS BOARD OF DIRECTORS}

President James J. De Yoreo, Lawrence Berkeley National Laboratory, USA Immediate Past President David S. Ginley, National Renewable Energy Laboratory, USA

Vice President and President-Elect Bruce M. Clemens, Stanford University, USA

Secretary Sean J. Hearne, Sandia National Laboratories, USA

Treasurer Michael R. Fitzsimmons, Los Alamos National Laboratory, USA Executive Director Todd M. Osman, Materials Research Society, USA

Wade Adams, Rice University, USA

Ana Claudia Arias, Palo Alto Research Center, USA

Tia Benson Tolle, Air Force Research Laboratory, USA

Flemming Besenbacher, Aarhus University, Denmark

Eberhard Bodenschatz, Max Planck Institute for Dynamics and Self Organization, Germany

Duane B. Dimos, Sandia National Laboratories, USA

J. Murray Gibson, Argonne National Laboratory, USA

Oliver Kraft, Karlsruhe Institute of Technology, Germany

Hideki Matsumura, Japan Advanced Institute of Science and Technology, Japan

Chris Orme, Lawrence Livermore National Laboratory, USA

Michael F. Rubner, Massachusetts Institute of Technology, USA

Takao Someya, The University of Tokyo, Japan

Susan E. Trolier-McKinstry, The Pennsylvania State University, USA

Pierre Wiltzius, University of California, Santa Barbara, USA

\section{MRS OPERATING COMMITTEE CHAIRS}

Academic Affairs Kalpana Katti, North Dakota State University, USA

Awards Julia R. Weertman, Northwestern University, USA

Government Affairs Alan J. Hurd, Los Alamos National Laboratory, USA International Relations Julia W. P. Hsu, The University of Texas, Dallas, USA Membership Shashi G. Jasty, Sigma-Aldrich, USA

Public Outreach Greta Zenner Petersen, University of Wisconsin, USA

Publications Paul McIntyre, Stanford University, USA

Technical Program Michael J. Aziz, Harvard University, USA

MRS OFFICE OF PUBLIC AFFAIRS

Ron Kelley 499 South Capitol St. SW, Suite 600, Washington, DC 20003
Editor

Gopal R. Rao, rao@mrs.org

Managing Editor

Judy Meiksin, meiksin@mrs.org

Technical Editor

Lori A. Wilson, Iwilson@mrs.org

Editorial Assistants

Ben Moriarty, moriarty@mrs.org

Mary Wilmoth

Associate Technical Editor

Carol Tseng

Art Director

Kasia M. Bruniany

Production/Design

Andrea Pekelnicky, Christopher R. Roberts, and TNQ

\section{Production Editor}

Catherine Paduani

Science News Editor

Tim Palucka

Principal Development Editor

Elizabeth L. Fleischer

Director of Publications and Marketing

Eileen Kiley Novak
Guest Editors

Gregory N. Parsons, Steven M. George, and Mato Knez

Special Contributors

Carl Blake, Charles Brooks,

Christopher L. Cahill, Émile Knystautas,

John M. Miller, and Jean Njoroge

Special Consultants

Babu Chalamala, Gan Moog Chow,

Renée G. Ford, and Alan Sellinger

Energy Quarterly

Steve M. Yalisove (Chair),

V.S. Arunachalam, Anshu Bharadwaj,

David Cahen, Russell R. Chianelli,

George Crabtree, Robin W. Grimes,

Abdelilah Slaoui, Guillermo Solórzano,

and M. Stanley Whittingham

Advertising/Sponsorship

Mary E. Kaufold, kaufold@mrs.org

Donna L. Watterson, watterson@mrs.org

Member Subscriptions

Michelle Judt, judt@mrs.org

Non-Member Subscriptions

subscriptions_newyork@cambridge.org

\section{EDITORIAL BOARD}

Paul S. Drzaic (Chair), Apple, Inc., USA

V.S. Arunachalam, Center for Study of Science, Technology \& Policy, India

Marie-Isabelle Baraton, University of Limoges, France

Robert C. Cammarata, Johns Hopkins University, USA

Laura Fornaro, University of Uruguay, Uruguay

Hanns-Ulrich Habermeier, Max Planck Institute for Solid State Research, Germany

Fiona C. Meldrum, University of Leeds, UK

Amit Misra, Los Alamos National Laboratory, USA

Julie A. Nucci, Cornell University, USA

Linda J. Olafsen, Baylor University, USA

David N. Seidman, Northwestern University, USA

Carol Trager-Cowan, University of Strathclyde, UK

Julia R. Weertman, Northwestern University, USA

Eric Werwa, Washington, DC, USA

Steve M. Yalisove, University of Michigan, USA

\section{VOLUME ORGANIZERS}

2012 Lei Jiang, Chinese Academy of Sciences, China Sergei V. Kalinin, Oak Ridge National Laboratory, USA Stéphanie P. Lacour, EPFL, Switzerland Steven C. Moss, Aerospace Corporation, USA

2011 Kyoung-Shin Choi, Purdue University, USA Reuben T. Collins, Colorado School of Mines, USA Sean E. Shaheen, University of Denver, USA Kathryn Uhrich, Rutgers, the State University of New Jersey, USA

2010 T. John Balk, University of Kentucky, USA David Cahen, Weizmann Institute of Science, Israe Fiona C. Meldrum, University of Leeds, UK Stephen K. Streiffer, Argonne National Laboratory, USA

MRS Bulletin (ISSN: 0883-7694, print; ISSN 1938-1425, online) is published 12 times a year by the Materials Research Society, 506 Keystone Drive, Warrendale, PA 15086-7573 Copyright $\odot$ 2011, Materials Research Society. Permission required to reproduce content. Periodical postage paid at New York, NY, and at additional mailing offices. POSTMASTER: Sen address changes to MRS Bulletin in care of the Journals Department, Cambridge University Press, 100 Brook Hill Drive, West Nyack, NY 10994-2113, USA. Printed in the U.S.A.

Membership in MRS is $\$ 115$ annually for regular members, $\$ 30$ for students. Dues include an allocation of $\$ 29$ ( $\$ 17$ for students) to a subscription to MRS Bulletin. Individual member subscriptions are for personal use only. Non-member subscription rates are $\$ 330$ for one calendar year (12 issues) within North America and $\$ 396$ elsewhere. Requests from subscribers for missing journal issues will be honored without charge only if received within six months of the issue's actual date of publication.

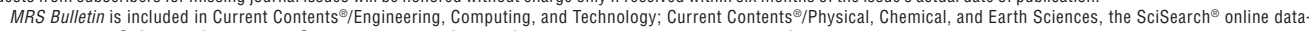
base, Research Alert $\oplus^{2}$ Science Citation Index ${ }^{\circledast}$, and the Materials Science Citation Index ${ }^{\top M}$. Back volumes of MRS Bulletin are available on microfiche through University Microfilms Inc, 300 North Zeeb Road, Ann Arbor, MI 48106, USA. 

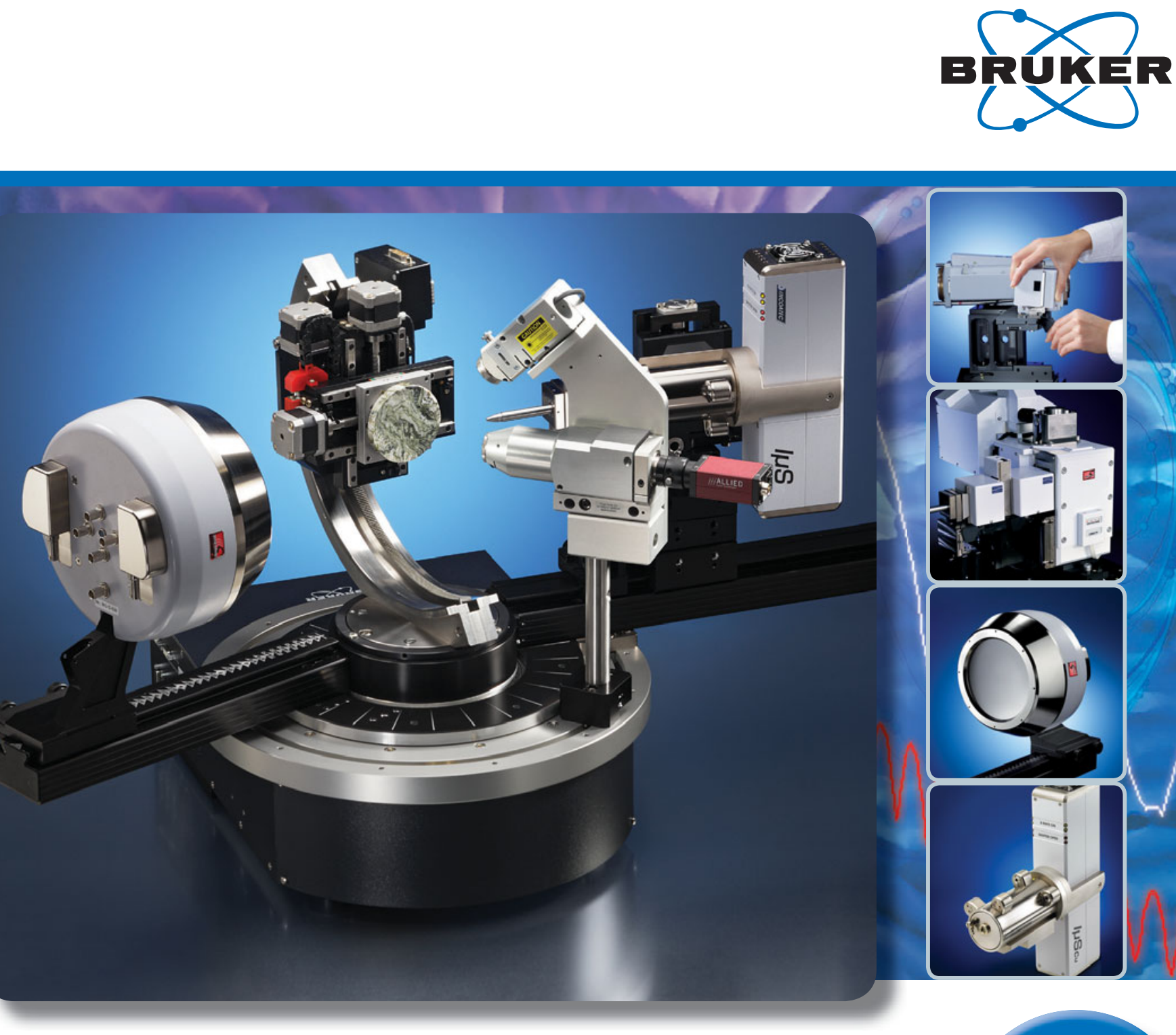

\section{D8 DISCOVER with DAVINCI}

\section{Microdiffraction the proper way}

- High-brilliance I $\mu \mathrm{S}$ : more maintenance-free photons

- TURBO X-RAY SOURCE: highest intensity for microfocus applications

- DAVINCI.SNAP-LOCK \& DAVINCI.MODE: alignment-free component change with real-time recognition

- Laser-Video microscope: measurements right at the point

- VÅNTEC-500: add the extra dimension of XRD²

Contact us for more details and a system demonstration! www.bruker.com/d8discover 


\section{Our Materials Inventory is the piece you've been}

missing.

- Inventory you need.

- Quality you require.

- Prices that meet your budget.

\section{Contact us for all of your materials research needs.}

\section{Kurt J. Lesker:}

Kurt J. Lesker Company

United States

412.387 .9200

800.245.1656

salesus@lesker.com

830
Kurt J. Lesker Canada Inc.

Canada

416.588.2610

800.465.2476

salescan@lesker.com
Kurt J. Lesker Company Ltd.

Europe

+44(0) 1424458100

saleseu@lesker.com

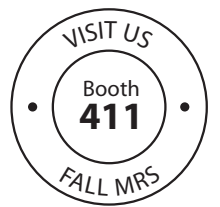

\section{www.lesker.com}

